\title{
Inside the Aid/Watch case: \\ translating across political and legal activism
}

\author{
James Goodman \\ University of Technology, Sydney
}

\begin{abstract}
The article explores the interaction between legal and political strategy in producing social change. It centres on a long-running dispute in Australia over whether charities can have a dominant political purpose. The focus is on the strategising of the small activist charity that successfully pursued the case over a five-year period. As an 'insider' account, the article charts the in-practice process of translating activisms across legal and political fields. With a stress on contingency and agency, the account affirms a 'politics of rights' approach to legal activism. It shows how the case opened-up new grounds for political contestation, and as such offered prospects for 'non-reformist reform'. It also demonstrates how this occurred more by strategic engagement with unintended effects, than necessarily by design.
\end{abstract}

There has always been a difficult relationship between legal and political activism, especially in liberal democratic societies. Political legitimacy in such societies centres on the Lockean contract between the national state and its citizenry, and is played-out in various modes of rights framing. Here, political contestation is channelled into rights claims that reinforce legitimation structures. Legal reforms, though, may prefigure wider transformations: as Andre Gorz argued, 'nonreformist reforms' can open up political spaces for mobilisation and broader forms of political claim-making (Gorz 1967, p.7; see Bond 2008). As argued here, the Aid/Watch case can be seen as an example of 'non-reformist reform', where a matter of minor legal irritation snowballed into a case that offers important political possibilities. As a battle between a small political charity and the machinery of the state, it affirmed political agency, demonstrating the possibilities as well as the tensions of fusing legal and political activism. In terms of the claims that were pursued, the case defines a new right to political 'agitation', whilst paradoxically affirming judicial structures. This article canvasses some of the dilemmas that arose during the conduct of the case, and is presented as a first-hand internal narrative.

Aid/Watch is a small member-based non-government organisation (NGO), with an income of less than $\$ 100,000$, which monitors the Australian Government overseas aid program. In 2006 the Australian Tax Office (ATO) disqualified Aid/Watch as a charity for having a dominant political purpose. For the following four years the organisation sought to overturn the ATO 
disqualification. It was ultimately successful, achieving its goal without spending one dollar of its members' donations. The case passed through five levels of appeal. Aid/Watch unsuccessfully appealed to the ATO in 2007, then in 2008 won its appeal at the Administrative Appeals Tribunal (AAT); the ATO successfully appealed against the AAT outcome at the Federal Court in 2009; Aid/Watch then successfully sought Special Leave to Appeal to the High Court. The High Court ruled in favour of Aid/Watch in 2010. Significantly, the case gave the High Court the opportunity to extend rights to political communication in Australia, thereby transforming Australian charity law, lifting the common law ban on charitable political purposes. The insistence by one small NGO that it had the right to speak-out as a charity forced the extension of constitutionallyentrenched rights in Australia.

It should be noted the Australian Constitution does little to protect human rights. As the Human Rights Commission states, the constitution 'offers only limited protection for a small number of discrete human rights': the right to trial by jury, freedom of religion, the right to judicial review, the right to compensation for compulsorily-acquired property and the right not to be discriminated against on the basis of State of residency (Australian Human Rights Commission 2009, paras 114 and 117). All other rights are subject to legislation and thus to limitation, the exception being the right to 'freedom of expression in relation to public and political affairs', commonly referred to as 'freedom of political communication', recognised by the High Court from 1992 as a constitutional right arising from the necessity for political debate in representative democracy (Australian Human Rights Commission 2009, para 118). In the High Court judgement for Aid/Watch this 'implied' right to political communication trumped the ban on political purposes for charities. Communication was broadly defined to include “"agitation” for legislative and political purposes', which the High Court defined as 'constitutional processes which contribute to public welfare’ (High Court of Australia 2010d, para 45; also see Williams in this Special Issue). The Aid/Watch case therefore enacts a constitutional guarantee for political 'agitation', and in the process raises important questions as to how this right to agitate may be similarly applied to benefit other fields of political life.

To help answer these questions, this article uses an 'inside' narrative to ask why this small organisation took on the task, and identify what factors enabled it to pursue the case. As a view from 'inside', the account is framed as a reflection on practice, with the benefit of hindsight, to draw out key themes and factors in the development of the case from an Aid/Watch perspective. 
In doing so, the paper addresses dilemmas between legal and political activism, within 'rights' framing, and beyond it.

As will become clear, there are many individuals from the NGO sector and amongst legal firms and in universities whose encouragement, sound advice and personal commitment played a central role in ensuring the case was pursued. One individual should be mentioned at the outset: the late Professor Mark Lyons, my former colleague at UTS, and authority on the not-for-profit sector in Australia, who encouraged us at every step. In 2003 he had commented 'From time to time the ATO has stripped a nonprofit organisation of its charity status on the ground that it transgressed the lobbying prohibition. These occasions are few and attract no attention' (Lyons 2003, p.1). With Aid/Watch, between 2006 and 2009 he played a key role in proving himself wrong. Unfortunately he passed away before the Federal Court Judgement was overturned.

\section{Legal and political activism 'in translation'}

In capitalist societies formal legal equality is in permanent tension with substantive inequality: paradoxically, formal equality enforces and institutionalises real inequalities. The extension of legal rights, from property rights, to political, social and cultural rights, reflects the extension of liberal principles across social fields (Marshall 1950/1973). The deepening Lockean contract does not supersede substantive inequalities, yet it renders them politically visible and open to challenge (Woods 1995). That challenge may come 'from within', for instance in the form of legal activism; or it may come externally, through political activism.

In debates about legal reform a continuum may be constructed between legal activism that limits itself to extrapolating existing legal principles, to political activism that aims to delegitimise the law, a form of immanent critique in the name of higher political norms. Legal activism seeks to extend rights observance, the assumption being that the legal regime can ameliorate the system that produces it. Taken alone, though, legal activism may enable de-radicalisation, cooptation and normalisation, entrenching the very power sources that are ostensibly being targeted (Lobel 2006). The target of immanent critique is the political system as a whole, and the legislative process as part of it, rather than legal authority per se. Pearson and Salter describe it as an 'effort to turn the normative standards that a legal ideology employs back upon the institutional procedures and actions which are supposed to embody these standards... [It] can involve taking a measure promising 'equal' rights 'at its word' even, or rather especially, where the underlying institutional intention was never to fully realise this ideal' (Pearson and Salter 1999, p. 484). An 
example is the call for 'animal rights' for 'enemy combatants' at the Guantanamo Bay military jail on the basis that dogs received better treatment at the jail than the human detainees (Zevnik 2011).

Clearly, legal and political activism can be linked. Legal activism on its own may proceed independently of political agency, but only within the existing legal framework. Shifting that framework requires political activism directed at publics beyond the immediate legal process. Immanent critique on its own is also inadequate: critiques may have wide political resonance, but are highly contingent. Extralegal activism, in a 'sphere of alternative social activism', may vacate the legal field in favour of a performative politics, which can lack traction (Lobel 2006, p. 981). Even if exposing contradictions forces regime change, a legal remedy is not guaranteed (and Guantanamo Bay may be a case in point).

Most often, though, the problem is of legal cooptation, where political movements give way to legislative initiatives, with political aspirations subsumed by legal norms. The diversion of political conflict into the pursuit of rights norms, in particular, can offer slim pickings: two cases that have received attention in the US, for instance, are labour movement demands during the 1930s New Deal era, and the Civil Rights movement in the 1960s, both of which are said to have been de-radicalised in the face of the legal rights bestowed upon them (Lobel 2007). To guard against cooptation, Scheingold, in his classic 1974 text, argued for a focus on the 'politics of rights' rather than rights as abstract legal claims (Scheingold 1974/2004). The politics of rights rejects the distinction between law and politics and puts political-legal strategising in the driving seat, offering the possibility of more sustained transformation. Yet the balance is a difficult one, especially given the in-built elitism of the legal profession, in tension with political activism, which relies on the mobilisation of broader publics.

Strategising between political and legal fields becomes a precondition for the kind of 'nonreformist reforms' favoured by Andre Gorz. The alternation should perhaps be understood as a process of strategic 'translation', from legal into political fields and vice versa (Paris 2006, p. 1029). Legal activism centres on the conduct of particular cases as they pass through various levels of judicial authority; political activism is also highly episodic, moving across issues and agendas according to the political process. The process of translation between the two is thus an active and on-going process of seeking to capture the agenda, a process which can be tracked and mapped. As a subjective engagement, the process involves individuals in strategic manoeuvres, in 
seeking-out 'strategic possibilities hidden within the concrete particularity of issues and movements' (Hunt 1990, p. 361). What is attempted here is a personalised mapping, to draw out the twists and turns across political and legal categories in the process of building a snowballing 'non-reformist reform'. Before embarking on this narrative, the following section provides some context on issue of charities and politics in Australia.

\section{Charitable status and advocacy in Australia}

The conservative Coalition that governed Australia 1996-2007 came to power with a mandate to rule for the 'mainstream' against 'special interests', as represented by advocacy NGOs. NGO elites were seen as impinging on the capacity of elected governments to govern for the mass of the populace, undermining economic efficiency and distorting the workings of the market (Staples 2007; Phillips 2006). The Coalition explicitly identified advocacy NGOs as unaccountable and self-serving, and sought to reduce their influence (Mowbray 2003). NGOs dependent on government funding were especially vulnerable: these were deemed to have violated public trust if they publicly criticized government policy, and could only advocate for individual cases, chilling public debate (see Maddison and Hamilton 2006).

Dependence on charitable donations from individuals and foundations was another source of vulnerability. Advocacy NGOs are often expert-based rather than member-based, and are particularly dependent on charitable status. For these organizations the capacity to establish and maintain a presence, and thus to influence the public sphere, can hinge on access to tax concessions. Government efforts to contain charitable status began in 2001, when the government initiated an inquiry into 'The Definition of Charities and Related Organizations' headed by a former judge, Ian Sheppard. The inquiry assessed what changes were necessary to ensure the legal definition of charities remained relevant to the contemporary environment, and unexpectedly recommended the definition of 'charitable purpose' be broadened. The inquiry found that advocacy could be a core element of charitable activity, provided it furthered or was 'in aid of... charitable purpose or purposes': any activity was acceptable provided it was not 'illegal', 'contrary to public policy', or involved promoting 'a political party or a candidate for political office ' (Commonwealth of Australia 2001, p.108).

In 2003 the Federal Government published its 'Draft Charities Bill', rejecting Sheppard's recommendations on advocacy. Within the Bill, under Section 8, a set of 'Disqualifying purposes' was created that included 'the purpose of attempting to change the law or government policy' 
(Commonwealth of Australia 2003). The Government referred the Bill to the Federal Taxation Board for public consultation, and about 260 submissions were submitted, mostly from the charitable sector. For many of these, the Bill's impact on advocacy was a central concern. For instance, Philanthropy Australia, a peak group representing 217 organisations, argued that: 'To exclude lobbying, advocacy or activities designed to achieve changes in government policy or legislation, is to take charities back 40 years. Such an exclusion would severely limit the effectiveness of many organizations...' (Philanthropy Australia 2003).

In its final report, the Tax Board described Section 8 as 'the most controversial section of the draft Bill', and added, 'concerns about Section 8 reflect the view that the Section may operate to limit the advocacy activities of charitable bodies. Respondents saw this possibility as significant because of the widely-expressed view that advocacy is of vital importance to the operations of the modern charitable sector' (Federal Taxation Board 2004, p.13). A key issue was the relationship between activities and purposes, and the extent to which a disqualifying purpose could be inferred from activities (Federal Taxation Board 2004, p. 21). In May 2004, in the face of overwhelming opposition from charities and churches, and from the National Roundtable of Non-profit Organisations, the Federal Government shelved the Bill.

With the legislative path blocked, the Federal Government moved to take the regulatory route. In 2003 the government had commissioned the Institute for Public Affairs, a 'free market' think-tank which itself has tax-deductible status, to audit the federal administration of charitable status. The IPA had established its own 'NGO Watch' project in 2001, and was a vocal critic of advocacy NGOs. At the time, Oxfam Community Aid Abroad condemned the Government for funding the IPA's 'smear campaign against charities, welfare and aid agencies' (Oxfam Australia 2003). The IPA's Project promoted the idea that charitable NGOs needed to disclose more information about their activities to the authorities, as part of a new 'protocol'. While the Government did not implement the Protocol, it did introduce new legislation that required charitable organizations to establish their credentials with the ATO in order to retain charitable status (Commonwealth of Australia 2004: Schedule 10 - Endorsement of Charities).

The legislation came into effect in 2005, strengthening the ATO's role in policing eligibility, and in 2005 the ATO issued tax rulings to clarify what criteria would be used to test eligibility. Despite the efforts of many organizations, including the National Roundtable of Non-profit Organisations, the eventual ATO Rulings imposed new limits on charitable activity. In particular, 
the ATO Ruling 2005/211 banned charities from having a purpose of 'propagating or promoting a particular point of view’ (ATO 2005, para 102). This disqualifying political purpose could be inferred from the organisation's activities: if such activity was deemed more than 'incidental' to the charity's purpose, then the organisation would cease to be a charity. The ATO reserved for itself the right to characterize the extent of political activity, potentially enabling it to deregister a charity whenever it took a 'point of view'.

\section{The Aid/Watch case from 'inside'}

Aid/Watch was set up in 1993 with the main aim of forcing greater accountability from Australia's agency for overseas development aid, AusAID. The ATO recognised Aid/Watch as a charity in 2000, and it was listed under the Register of Environment Organisations for Deductable Gift Recipient Status. I joined the Aid/Watch Committee of Management in 1998, having worked with the organisation in the successful campaign against the OECD’s Multilateral Agreement on Investment. By 1998 Aid/Watch had developed an organisational model that remains in place today, namely a focus on researching and campaigning with people affected by the Australian aid program. The organisation attracted a small but loyal membership base, many of whom provided tax-deductible donations, and it received several project grants from international charitable foundations.

\section{Aid/Watch Disqualification - 2006}

The ATO’s 'Notification of Revocation of Endorsement as a Tax Concession Charity' was issued to Aid/Watch in October 2006. The notice recognised that Aid/Watch objectives, as stated in its constitution, were charitable, and were fulfilled through a range of different research and education activities, including through the provision of advice to governments in Australia and overseas. However the ATO cited three activities of the organisation that it believed were not consistent with charitable status. These three 'political' activities were: urging the public to write to the Government to put pressure on the Burmese regime; delivering an (ironic) 60th anniversary birthday cake to the World Bank; and raising concerns about the developmental impacts of the US-Australia Free Trade Agreement. The ATO claimed the three activities were more than incidental to Aid/Watch's charitable purpose and demonstrated that Aid/Watch had a 'separate, political purpose' ${ }^{1}$

\footnotetext{
${ }^{1}$ ATO, Notification of Revocation of Endorsement as a Tax Concession Charity, 2 October 2006.
} 
The arrival of the ATO's disqualifying letter sparked an intense debate within Aid/Watch. Given the ATO's grounds for disqualifying Aid/Watch, there was a strong view that this was a political decision, driven by members of the government. During the decade of conservative rule, from 1996, the Australian aid program had become increasingly politicized, and tensions between Aid/Watch and the government had sharpened. In 2006 for instance, Aid/Watch released research highlighting the misuse of Tsunami aid to Indonesia, and the Foreign Minister telephoned Aid/Watch offices, threatening to de-fund the organization (he was informed that under its constitution the organization could not accept government funding).

The ATO, itself, denied any political motivation in disqualifying Aid/Watch. At a mediation session required by the Administrative Appeals Tribunal (AAT) in April 2008, the ATO refused to disclose how it had identified Aid/Watch from the 48,000 organisations that had tax-exempt charitable status. In a written response, the Australian Government Solicitor stated that to 'maintain the integrity of compliance programs' the ATO could not reveal the 'manner and method of selecting individuals and entities for audit'. ${ }^{2}$

Efforts at alerting the new Labor Government, that came to power in 2007, to questions of political bias, met with a similar response. Separate letters from Federal Ministers, Bob McMullan as Minister for International Development Assistance responding to a constituent, and Wayne Swan as Treasurer responding to Senator Brown, insisted the ATO was 'independent' and ‘impartial’ (27 July 2007 and 15 January 2009 respectively). More detached observers of the process suggested that governments had kept the compliance system deliberately opaque, 'as a useful weapon of bureaucratic discretion... a weapon they could wield against certain organizations’' (Lyons 2003, p.1).

The actual character of the compliance program was inadvertently revealed at a November 2008 Federal Inquiry into 'Disclosure regimes for charities and not-for-profits' when Deputy Commissioner Mark Konza told the inquiry that the ATO investigated Aid/Watch following an 'intelligence lead' (Senate Standing Committee on Economics 2008, p. 22). Ironically, Mr Konza breached the ATO's own confidentiality obligations, and acknowledged he was doing so, when he agreed with a Senator that Aid/Watch was the only organisation denied charitable status on political grounds, claiming it 'was only engaged in political activity'. Intriguingly, Mr Konza appeared to acknowledge that a Liberal Senator, Senator Mason, had been the source of the

\footnotetext{
${ }^{2}$ Australian Government Solicitor, Letter to Aid/Watch, 14 May 2008.
} 
complaint against Aid/Watch. In a follow-up discussion Mr Konza also put on the public record that the ATO would initiate investigation of the groups involved in the 'Make Poverty History' campaign, and also the Wilderness Society should a formal complaint about these organisations be forthcoming from Senator Mason.

These informal exchanges, recorded in Hansard, reveal much about the regime that was in place, despite the ATO's official insistence that it was (and is) independent of government. This was the position put to Senator Brown in response to a series of questions he submitted to the Treasury on the Aid/Watch case and the apparent politicisation of the ATO. In response, the Treasury had stated that secrecy laws prevented the Tax Commissioner from raising individual cases with the Government (and vice versa). As such Treasury denied there had been any discussion with members of the Government about the ATO’s decision to launch a Federal Court appeal to overturn the AAT Aid/Watch decision. It insisted: 'the Tax Office review of NGOs is based on an understanding of the legal requirements and is no way influenced by the Government' (Senate Standing Committee on Economics 2009, para 5).

\section{Internal ATO Appeal - 2007}

The political context in which Aid/Watch was selected for disqualification influenced the approach taken internally. With the help of a pro-bono lawyer, Aid/Watch lodged an internal ATO appeal in late 2006 against the disqualification. In the meantime Aid/Watch also looked at the possibility of revising its constitution in order to make clear that its activities conformed to ATO guidelines. This conciliatory approach was forced off the table when the ATO responded to the Aid/Watch appeal by arguing that some of Aid/Watch purposes were disqualifying political purposes, as well as the three cited activities. ${ }^{3}$ Further, at a mediation later required by the AAT, the ATO refused to state what form of words would be required in order to meet their requirements: Aid/Watch would have to accept disqualification and reapply. ${ }^{4}$ In light of the ATO’s response to the Aid/Watch appeal, an overall strategy coalesced around a political campaign to promote a legal challenge.

First, though, Aid/Watch had to decide whether they indeed had any chance of success. After the ATO appeal Aid/Watch the pro bono lawyer stated they had 'formed the view that Aid/Watch does not have a reasonable prospect of success in appealing', and declined to continue assisting

\footnotetext{
${ }^{3}$ Australian Tax Office, Reasons for Decision, Aid Watch Inc. Objection Reference 5567873.

${ }^{4}$ Aid/Watch, Notes from Aid/Watch Mediation, 30 April 2008.
} 
the organisation. ${ }^{5}$ The lawyer was from one of Australia's leading law firms, and its decision to drop the case was a major blow. Fortunately, Aid/Watch was also being informally advised by several lawyers based within large charitable NGOs. These individuals played a key role in persuading Aid/Watch that it was worth taking the case further. Their strong recommendation was to appeal the case to the AAT as, if the appeal failed at the Tribunal, ATO legal costs could not be imposed on Aid/Watch. The question of financial liability for the Aid/Watch Committee of Management, at this stage, was therefore not a major concern. Given the risks were low, Aid/Watch began searching for a new source of legal representation.

Aid/Watch now decided to politicise the ATO's decision, to define it as a test case for the charitable sector as a whole. With no further hope of persuading the ATO to change its position, Aid/Watch planned to target the ATO as having made an arbitrary and politicized decision. This would strengthen support from the NGO sector, and help in sourcing legal representation. A wide range of development and environment charities were approached, and also other commentators, to brief them on the case. Specific journalists were contacted and a broadsheet news story was developed to coincide with a public announcement that Aid/Watch had been disqualified. Publicising the ATO disqualification was timed deliberately with a major Aid/Watch critique of the aid program: on 28 May Aid/Watch was in the media accusing the government of having manipulating the aid program; on 30 May a media story outlined how the organisation had been disqualified for its political activities (Jopson 2007; Wade 2007). Also, on 29 May Aid/Watch used a budget estimates hearing in the Federal Parliament to question the ATO, with the Greens Senator Kerry Nettle asking a range of questions of Michael D’Ascenzo, Commissioner of Taxation and Senator Nick Minchin (then Minister for Finance). ${ }^{6}$

The media visibility politicized the case, and a wide range of NGOs began raising concerns. A number of prominent aid charities asserted the importance of charitable advocacy for a democratic society. The chief executive of Oxfam, Andrew Hewett, stated the decision was negative for the sector, for public policy and for governance in Australia; the chief executive of World Vision, Tim Costello, stated advocacy was inseparable from charity, even in the most immediate and direct forms of humanitarian assistance (see Wade 2007 and ABC News 2007a). The peak aid NGO, the Australian Council for International Development (ACFID, ACFOA's successor), was concerned the case would send a 'disturbing, anti-democratic signal across

\footnotetext{
${ }^{5}$ Aid/Watch Confidential Source, Lawyers Letter, 2 May 2007.

${ }^{6}$ The Commissioner stated that charities had to be engaged in the 'direct provision of assistance', claiming indirect advocacy was not charitable; see Senate Standing Committee on Economics 2007.
} 
Australia’s large non-profit sector' (ACFID 2007). There was also a strong response from the social services sector, with the Chair of the National Roundtable of Non Profit Organisations, David Thompson, stating: 'if we're to have a robust, transparent and effective democracy, we need organisations like Aid/Watch doing the homework' (ABC News 2007b). The Chief Executive of The St Vincent De Paul Society, John Falzon, stated in an article devoted to the case that 'we will never countenance a concept that charitable assistance should be separate from advocacy’ (Davies 2007).

At the time, and after, Government hostility increased. The Secretary to the Treasurer, Peter Dutton, stated Aid/Watch was seeking to make 'political mileage' out of the ATO decision, demonstrating the 'sort of organisation that they are' (ABC News 2007b). When Aid/Watch released a report in June 2007 that criticized the use of Australian aid to gain access to the Iraqi wheat market, the Foreign Minister's office simply labelled Aid/Watch 'extremist' (ABC News 2007c). Nevertheless, the legal case was being seriously assessed by tax advisors and charity lawyers. Even a former ATO auditor raised concerns at the increasing politicization of the ATO, stating the case needed 'to be examined by the external authorities' (Seage 2007). In August 2007 a not-for-profit briefing on the case from a Melbourne-based legal firm, Moores, stated: 'pressure by the ATO on perceived political activities of charitable and especially overseas aid organizations is at odds with contemporary thinking that real change will come about when governments intervene to deal with the causes of poverty rather than alleviating the outcomes of poverty' (Irvine-So 2007). It added: 'The difficulty for charitable organizations is to work out when an ancillary activity may become so dominant that it becomes a purpose in itself. At the moment there is little guidance and the outcome of the Aid/Watch case will help. In the meantime there is danger in extensive or aggressive political activity...' (Irvine-So 2007).

Political visibility defined the case as a possible public interest test case, and helped Aid/Watch find pro bono legal representation with the progressive legal firm, Maurice Blackburn, through its 'Social Justice Practice'. This was a key stage in the case, as it later shifted the legal frame, from a largely tax and charity law focus into a constitutional context, offering broader possibilities for a legal remedy.

\section{Administrative Appeals Tribunal - 2008}

The AAT case was listed for June 2008; the AAT waived the application fee and the AAT President Justice Downes presided over the case. A mediation between Aid/Watch and the ATO 
prior to the case hearing was required (against ATO objections). Rather than mediating the case, this further entrenched the legal dispute: the ATO now argued that because the Aid/Watch constitution sought 'to ensure' aid was more effectively distributed, then by definition it had a dominant political purpose. In their submission responding to the AAT appeal the ATO now argued that 'all of the applicant's objects seek to change law or policy', and hence that all of the Aid/Watch purposes were political (ATO 2008, para 3.4).

The AAT appeal was a major task for Aid/Watch as it required extensive evidence, linked to legal arguments that the organization conformed to the existing common law on the definition of charity. Importantly, the process of making the argument from within the existing legal framework was in some tension with the political stance that charities had the right to speak out. The legal argument at the AAT turned on whether Aid/Watch sought to propagandize for changes in the law, or undertook monitoring, research and campaigning to improve the administration of the aid program. In some respects, the organization would defend the right to do either or both of these: the argument that charities should be allowed to speak out does not discriminate on how they do this. At the AAT though, Aid/Watch argued its activities were not aimed at changing the law, but rather at helping the government implement AusAID’s policy commitment to alleviating poverty and promoting environmental sustainability.

The two-day hearing involved two large legal teams, an Aid/Watch witness, and Justice Downes. The ATO had trawled through the Aid/Watch website, and had made several requests for internal documents, including funding applications, notes from planning sessions, and minutes of meetings. Several additional papers, mined from the Aid/Watch website, were unexpectedly tabled on the day. The judgement, when it came, was in favour of Aid/Watch: its purposes were found to be directed to the relief of poverty and the advancement of education, and also otherwise of benefit to the public; its political activities were found to be 'encouraging' the realization of existing government policy on aid, not 'opposing' it (AAT 2008: para 6). Significantly, the judgement explicitly stated that Aid/Watch did not have to distribute aid in order to be charitable: 'the objects are charitable notwithstanding the fact that Aid/Watch does not itself provide aid' (AAT 2008, para 7).

The AAT hearing was to prove invaluable as it set a benchmark establishing the 'facts of the case': in formal terms subsequent appeals could only be pursued on the basis of legal arguments, as against questions of fact. For Aid/Watch this was welcome, as it meant there would be no need 
for further evidence to be presented. In large part, from then on, direct participation in the legal case was in the hands of the lawyers.

\section{Federal Court - 2009}

In responding to the AAT judgement the ATO insisted that Aid/Watch was still no longer a charity, and signaled it would appeal to the Federal Court. To overturn the judgement the ATO needed Aid/Watch to mount a defence, and hence had to concede that the matter was a test case for the sector. As such, the Aid/Watch legal defence at the Federal Court was funded from the ATO’s 'Test Case Litigation Program', and Aid/Watch was indemnified against the ATO’s legal costs. For the organization, then, the ATO’s Federal Court appeal had minimal impact: the case was defended against the ATO solely through legal arguments centring on charity law, and given the test case funding, there was no financial risk to the Committee of Management.

The real risk, though, was that the ATO would succeed in their appeal, and this risk was now not simply to Aid/Watch, but to the sector as a whole. The case was being treated as a test case, and the ATO, in their submissions, were clearly seeking to deepen the ban on political charity. The ATO now argued that Aid/Watch could not have a purpose of relieving poverty as it provided no direct relief (ATO 2009, 4.2), and also that it could not have public education purpose as it failed to offer a 'syllabus' (ATO 2009, 4.3). As such, the ATO was now seeking to delimit the definition of charitable purposes as well as extend the scope of the political disqualification. At the AAT, Aid/Watch had successfully argued it was helping the government implement its own policies on overseas aid: at the Federal Court the ATO, quite remarkably, argued there was no such policy, that legislation 'does not indicate that the present Australian Government supports overseas aid' (ATO 2009, 2.8). The ATO also maintained its position, as expressed at the AAT, that Aid/Watch sought to 'ensure' the effectiveness of the government's overseas aid program, and as such by definition had a dominant political purpose.

The Federal Court judgement of September 2009 overturned the decision of the AAT and found in favour of the ATO. Significantly, though, it did recognise that Aid/Watch had a clear charitable purpose in aiming to alleviate poverty, and that it did this by monitoring the aid program (Federal Court 2009, para 20). It thus rejected the ATO’s claim that charities must be involved in directly alleviating poverty if they are to be defined as a charity. It also rejected the ATO's argument that 
conducting and publicising research, as undertaken by Aid/Watch, could not be defined as public education (Federal Court 2009, para 29).

On the question of whether there was a disqualifying political purpose, though, the court agreed with the ATO, arguing that Aid/Watch had a dominant political purpose because its constitution seeks 'to ensure' that aid alleviates poverty. The Court fully accepted this argument:

‘Aid/Watch's attempt to persuade the government (however indirectly) to its point of view necessarily involves criticism of, and an attempt to bring about change in, government activity and, in some cases, government policy. There can be little doubt that this is political activity and that behind this activity is a political purpose. Moreover the activity is Aid/Watch's main activity and the political purpose is its main purpose.' (Federal Court 2009, para 39). What disqualified Aid/Watch, for the Court, was that it sought to ensure 'that the delivery of aid should conform to its view' (Federal Court 2009: para 41; bold in original). Attempting to influence the public to change government practices was now unacceptable, as well as attempts to directly influence the outcome of legislation or policy: as such, the Court substantially deepened the political ban (Federal Court 2009, para 47).

Aid/Watch cried foul, stating the judgement narrowed the scope for charitable advocacy. Specifically, Aid/Watch argued the judgement was contradictory: as a charity Aid/Watch could devote itself to monitoring the aid program in order to educate the public and alleviate poverty. But it could not take a view on the aid program, begging the question of how it could fulfil its purposes. Responses from the media and from legal observers affirmed the broad anticipated impact on the sector, with concerns widely expressed: the Australian Financial Review reported 'Ruling threatens charities', the Australian stated 'Tax battle may affect advocacy bodies'; sector journals and think tanks responded in a similar way, and senior charity lawyer, Murray Baird, flagged the necessity for a High Court appeal (Jacobs 2009; Callick 2009; ABC Radio National 2009; Third Sector Magazine 2009; The Australia Institute 2009).

The Judgement was certainly a very negative outcome for the sector. There was always a risk that the Aid/Watch case would give the ATO an opportunity to further tighten charity law. Such a possibility had been discussed internally at Aid/Watch before the decision to proceed with the AAT appeal: lawyers based in the larger NGOs had stated that the 2006 Notification itself had established a precedent, and that it had to be challenged. But now the stakes had risen substantially: a Notification, or indeed a failed AAT appeal would have had less significance than 
a Full Federal Court Appeal Judgement. Clearly, for the sector as a whole, the situation had deteriorated.

\section{Application for Leave to Appeal to the High Court - 2009}

If it was important to contest the original ATO Notification, then certainly it was vitally important to find a way to overturn the Federal Court Judgement. But if the legal stakes had risen, then so had the financial stakes. If Aid/Watch was to appeal to the High Court it would first have to apply for Special Leave to Appeal. This in itself, if it failed, could leave Aid/Watch liable to pay the legal costs of the ATO. The Government Solicitor had already indicated that it would seek to recover these costs, which were estimated as in the order of $\$ 70,000$. The Aid/Watch Committee of Management had to find a risk-free means of appealing to the High Court or face a financial liability. Under the NSW rules of incorporation individual members of management committees are personally liable if a debt is incurred when 'there are reasonable grounds to expect that the association will not be able to pay' (NSW Government 1984, article 38.1). To deal with this, the management committee held specific meetings on the issue, and ensured that the organization's strategy for minimizing the risks was thoroughly minuted.

The strategy came in two parts. The first element was to approach the NGO sector and seek a financial 'backstop' of at least $\$ 70,000$ to insure Aid/Watch against any possible liability incurred by applying to appeal to the High Court. The second element was to decide that Aid/Watch could not proceed with the High Court appeal if the ATO failed to provide test case funding. The ATO had refused test case funding for the Application for Special Leave to Appeal, but there had been some informal suggestion that if the special leave application was successful then a request for test case funding would be looked at more favourably.

In mid 2009 the management committee sought to raise the guarantees from NGOs. In terms of the legal arguments, Maurice Blackburn and the barristers had listed a series of reasons why the application was likely to be successful. The Federal Court itself had prefigured a High Court appeal, stating 'this area of Australian law is informed by concepts which, due principally to their antiquity, are not easily adapted to the modern context', emphasising that 'as an intermediate appellate court' it was limited in its capacity to do this (Federal Court 2009, paras 9 and 45). Additionally, the case had sector-wide implications, and was in an area of legal uncertainty. Most important, following the Federal Court judgement, the case now hinged solely on the question of political purposes. 
The response from NGOs was encouraging: about fourteen organizations were formally approached, and only two were unable to provide a guarantee. The organizations were in the main from the overseas development and environment sectors, and all agreed that given the Federal Court judgement, a High Court appeal had to go ahead. In addition, several other organizations, including the St Vincent de Paul Society, and peak organizations such as ACOSS and ACFID, agreed to write to the High Court urging it allow the appeal to go ahead. With the $\$ 70,000$ guarantee in place, the Aid/Watch management committee made the decision to go ahead with seeking special leave to appeal.

At the hearing itself, in March 2010, the Court asked little of the Aid/Watch side, and instead focused on the ATO and its team of lawyers (which were now headed by D.M.J. Bennett QC, former Solicitor-General for the Howard Government). The Court agreed with Aid/Watch that there were grounds for the High Court to consider whether or not the Australian Taxation Office should have revoked charitable status in 2006: Justice Gummow did not agree with the ATO argument that this was an 'inconvenient vehicle' for a test case, and asked of the ATO, 'what is offensive in influencing government?' (High Court of Australia 2010a). The Court noted that the role of government in addressing poverty had significantly changed over the past 150 years and agreed that the appeal should go ahead.

\section{High Court Appeal - 2010}

With the High Court appeal pending, the financial risk to Aid/Watch had multiplied. If Aid/Watch lost the High Court appeal, the Government Solicitor would most likely seek to recover costs, both from the appeal and from the special leave application, a total bill approaching $\$ 300,000$. Aid/Watch lawyers again submitted an application to the ATO for test case funding, this time arguing that given the High Court would now hear the appeal, the case had indeed become a test case for the sector.

Ironically enough, Aid/Watch was unable to take its appeal against the ATO without the ATO funding. If the ATO refused to fund the case, Aid/Watch could have argued the ATO was denying natural justice, as the ATO had used test case funding to overturn the AAT outcome. Aid/Watch could also have argued the case demonstrated the necessity for legislation. But even then, the financial prospects were not good: even if Aid/Watch had dropped the case, it could still face the possibility of a $\$ 70,000$ bill from the ATO (and it seemed unlikely the NGOs that had supported 
the special leave application would be willing to waste funds on an appeal that was never pursued).

For a fortnight the ATO considered the test case funding application: Aid/Watch sought to exert some pressure, releasing details of the financial 'backstop' and stressing widespread NGO support for the case to be heard, which were reported extensively in the Australian (Callick 2010). It was only on the evening of the Thursday before the 2010 Easter Bank Holiday that the Aid/Watch lawyers finally took a call, from the Assistant Commissioner himself, saying that after some deliberation, the ATO had decided to fund the case. This was an important moment for Aid/Watch. With the ATO funding the case, Aid/Watch was assured its lawyers would be paid, and that Aid/Watch would be indemnified against the ATO's costs should the appeal fail. Maurice Blackburn could prepare the full High Court appeal.

At this stage Aid/Watch was still arguing within the frame of charity law, that charitable activity could be political and should not be construed as a dominant purpose. In late 2010, for instance, Aid/Watch had made a submission to the Productivity Commission Inquiry into 'The Contribution of the Not-for-Profit Sector', arguing that the government should adopt the Sheppard Inquiry recommendations so that charities could engage in 'lobbying, research and monitoring' as well as direct service provision (Goodman 2009). In hindsight, Aid/Watch had begun to believe its own legal arguments, basing the approach on the existing charity law, rather than on in-principle commitments. What had been a legal strategy in the service of a political principle had become a legal dispute on the finer points of charity law.

The appeal papers submitted to the High Court - both the Application for Special Leave to Appeal, and the Appellant's Submissions - directly challenged the extension of the political disqualification rule under the Federal Court judgement. The special leave application argued that 'many Australian charities indirectly attempt to influence government', and thus are endangered by the Federal Court judgement, posing a 'substantial risk of grave injustice in the future' (Aid/Watch 2009, paras 44 and 45). The Respondent's Submissions, from the ATO lawyers, argued that the 'political disqualification principle' applied at any 'level of generality', whether in terms of overall goals, means, or activities (ATO 2010, paras 7 and 39).

To resolve this problem, the Aid/Watch submissions made a positive constitutional argument in favour of the public benefit of political debate. The Federal Court Judgement had stated the Court 
could not usurp the legislative political process and sit in judgement over the merits or otherwise of the points of view promoted by Aid/Watch: it simply ruled them to be political and the organisation to be uncharitable. Aid/Watch submissions to the High Court sought to up-end this argument, stating that political debate is by definition in the public benefit. Submissions cited the implied right to freedom of political communication, established by the High Court since 1997, that 'recognises the public benefit in the dissemination and receipt of information, opinions and arguments concerning political matters which affect the people of Australia' (Aid/Watch 2009, para 31). The claim that promoting public debate on political issues is by definition in the public benefit was sharply contested in the respondent's submissions, which asserted 'mere discourse is not a public benefit' and argued the High Court had not ruled political debate should be supported by tax-exempt charitable status (ATO 2010, paras 52 and 53).

Here, the Aid/Watch lawyers and barristers raised the legal stakes beyond these limits of charity law, and very effectively reframed the case. In part this reflected the High Court jurisdiction, where broader questions of political principle could be translated into legal arguments around constitutional rights. It also reflected the public interest focus of the lawyers, and the extent to which they were able to reframe the case in constitutional terms. In the process, at the High Court hearing they were able to capture the legal agenda, and put the ATO lawyers onto the defensive.

As a result of this reframing, the High Court appeal itself centred largely on the Aid/Watch argument that silencing charities was an unwarranted restriction on freedom of political communication (High Court of Australia 2010b). In its own terms, the ATO’s political disqualification prevented charities from having a dominant political purpose, and as such delimited political communication. Not surprisingly, the ATO preferred a very broad definition of what constituted 'political' activities, and hence what could be construed to be a dominant political purpose. The result was a direct and extensive constraint on political communication for any organisation holding charitable status.

Aid/Watch lawyers argued that the common law disqualification only applies to purposes contrary to public policy, rather than much broader political purposes. This public policy disqualification would simply require that charities not act in ways that are contrary to the law. The Aid/Watch lawyers argued this latter constraint was already established in the case law, and would be more suited to the Australian constitutional context. Members of the bench were concerned that the public policy approach may allow political parties to gain charitable status - a 
point answered by Aid/Watch barristers, who suggested the courts could disqualify political parties on the basis that charitable status would entrench a political party in office. This would contravene the constitutional commitment to representative democracy, and thus would be contrary to public policy.

The ATO's main objection to the argument that political disqualification violates the doctrine of freedom of political communication was that the doctrine is recognised by the High Court as a negative freedom, not a positive freedom. The ATO is thus not obliged to use its charitable tax concessions to encourage freedom of political communication. Charitable status, the ATO argued, is simply a privileged status awarded to certain categories of organisation that perform a particular role in society (High Court of Australia 2010c). The problem for this argument was that the legislature had in 2004 itself chosen not to define charitable status in Australia. As such, members of the Bench stated the High Court should not concern itself with the legislative context - it was an irrelevance.

Crucially, then, the High Court was free to develop the common law in the area. In doing so it would not in any way usurp the role of the legislature: the legislature had opted-out. The ATO lawyers very strongly objected to this argument, suggesting that the consequences could be very negative in terms of lost revenue if the political disqualification rule was lifted, as a result of many more organisations qualifying for charitable status. This claim was literally ruled out of court, as a matter for the ATO, not for the High Court.

The remainder of the ATO's defence centred on whether or not Aid/Watch acted in the public benefit. A distinction was drawn between biased political speech, attributed to Aid/Watch, and genuine efforts at raising issues in ways that do not prejudge outcomes. An analogy was drawn between propagandizing and debating. In making these points the ATO repeatedly referred to specific viewpoints adopted by Aid/Watch. Despite being informed by the Bench that freedom of political communication was a freedom to engage in any form of legal political rhetoric, the ATO returned repeatedly to the content of Aid/Watch materials (High Court of Australia 2010c). Each time this was attempted, the Bench responded by asking how this was relevant, pointing out that it was not the role of the High Court to rule on the content of political communication, but simply on the freedom to engage in it. 
A similar move emerged with the ATO's argument that Aid/Watch did not serve the public benefit. The ATO barrister spent some time asserting that Aid/Watch was not effective in discharging its responsibilities, and that this meant it could not be described as having public benefit. The Bench responded by asking how the question of effectiveness was relevant to purposes. Again, it appeared the ATO's main reason for making these assertions was to discredit Aid/Watch in a context where the organisation could not effectively respond.

The key argument remained: the common law of charity in Australia had to move with the times. Given the legislature had failed to act in this area, it was up to the High Court to resolve a potential clash between the constitutionally-entrenched freedom of political communication, and the existing law of charity. One had to give way to the other.

The majority judgement, 5-7, when it came in December 2010, favoured the constitutional norm: it overturned the Federal Court judgement, finding in favour of Aid/Watch, and updating the common law on charity to make it consistent with freedom of political communication. Departure from English common law was necessary as it had not been developed with regard to the 'Australian system and government established and maintained by the Constitution itself'; reflecting that system, the High Court ruled that 'the generation by lawful means of public debate... itself is a purpose beneficial to the community' (High Court of Australia 2010d, paras 40 and 47). In the process, the High Court established a distinctive Australian law on charitable advocacy, of great significance both for the sector and for broader questions of political engagement and 'agitation' in Australia, and internationally; as The Australian put it, 'the 'implied right is back in business' (Pelly 2010). ${ }^{7}$

\section{Conclusions}

The narrative reveals an oscillation between legal and political spheres during the conduct of the Aid/Watch case, from 2006 to 2010. That oscillation continued after the High Court judgement as Aid/Watch and others sought to ensure that the ATO implemented the judgement in a way that would lift the political disqualification for all charities. The importance of this was made clear at public forums held in Melbourne and Sydney in early 2011, where some of the ambiguities in the

\footnotetext{
${ }^{7}$ The case was cited as having implications for other jurisdictions, notably in New Zealand and the UK, see Wiggins 2011.
} 
judgement were highlighted and debated. ${ }^{8}$ The forums were significant as they demonstrated that the sector's expectation was that the ATO should now permit a dominant political purpose for all charities. In the event the ATO fulfilled this expectation.

The ATO’s draft ruling on charities issued in May 2011 responded to a range of High Court cases on charitable status, including the Aid/Watch case. In terms of political purposes, the draft ruling simply lifted the political disqualification: it stated that 'following the High Court's decision in Aid/Watch... an entity can be charitable if it has a purpose (including a sole purpose) of generating public debate with a view to influencing legislation, government activities or government policy in relation to subject matters that come within one or more of the four heads of charity’ (ATO 2011a, para 68(i)). Importantly, there was no requirement to present a balanced position: 'an entity does not necessarily have to present a balanced position in order to be considered an entity with a purpose of generating public debate' (ATO 2011a, para 68(iii)). There was some uncertainty about areas of public policy and public debate that may sit outside the four heads of charity, to be decided 'on a case by case basis'; there was also a requirement that charitable political purposes involve public debate, not private lobbying, and not party-political activity.

After a period of public consultation the finalized ruling was released in October 2011, replicating much of what appeared in the draft version, at least in respect of the Aid/Watch case (ATO 2011b, paras 70-74). There was even some further loosening of the political constraints, with the mention of lobbying dropped from view, and the ban on associating with political parties confined to organizations that have this as their 'sole purpose' (ATO 2011b, para 72). As such, the ATO ruling, finalized in October 2011, confirmed that the Aid/Watch case produced a significant change in the Australian law of charity. But the story was by no means over, with the Government seeking to revive the statutory route that had been abandoned in 2003.

In parallel with the High Court case, in the May 2011 budget the Government had initiated its own process for developing a statutory definition of charitable status in Australia. The new

\footnotetext{
${ }^{8}$ The papers in this Special Issue were presented at two of these forums. The first was held at the Melbourne Law School in February 2010; the second was hosted in Sydney by the UTS Cosmopolitan Civil Societies Research Centre. There were two further forums, with input from the ATO, organised by ChangeMakers Australia, which also made several submissions to the ATO on the issue. See: www.changemakers.org.au
} 
statutory definition of charity was to be revenue neutral ${ }^{9}$ and was to be 'based on the 2001 Report of the Inquiry into the Definition of Charities and Related Organisations, taking account of the findings of recent judicial decisions, such as Aid/Watch Incorporated v Commissioner of Taxation' (Treasury 2011, 37). In late October 2011 the Treasury opened public consultations on the basis of a paper, leading to an exposure draft of legislation in 2012. Surprisingly, instead of using the 2001 Sheppard Inquiry, Treasury chose to 'base an Australian statutory definition on the work already done on the Charities Bill 2003', a Bill that had been widely discredited (Treasury 2011, para 41). ${ }^{10}$ Reflecting the 2003 Bill, Treasury sought to elevate a strengthened 'public benefit' test, which could have the effect of cancelling-out the High Court insistence that public debate on matters of public policy has an intrinsic public benefit (Treasury 2011, para 111).

While the issue of charitable advocacy has moved back into the political sphere, certain constitutional safeguards had been put in place. The Aid/Watch High Court ruling relied upon the implied freedom of political communication, and was grounded in Australian constitutional law as much as in the common law of charity. As such, any statutory definition of charitable status would have to comply with the constitutional protection of public debate on political matters. Nevertheless, ensuring such protection is vested in the statutory provisions would no doubt require continued political pressure and possibly still further legal activism. The necessity for ongoing 'translation' across political and legal fields remains in place. But most important, if the new rights to political expression and 'agitation' are not claimed and tested by existing charities, and indeed by political organizations seeking charitable status, they will surely wither on the vine.

Setting aside the on-going drama of defining charitable status, this account of legal and political activism by one small NGO has been aimed at detailing the contingent character of the political and legal process. Nothing in this narrative was given from the outset - the foundations for legal change were created in the process of contestation. As such, what the narrative reveals is a process of strategizing and translating across legal and political fields in order to accumulate forms of leverage. There is no evidence here that political pressure influenced the legal outcomes, rather, we see political activism laying and re-laying the foundations that enabled various levels

\footnotetext{
${ }^{9}$ The new Australian Charities and Not-for-profits Commission, which was to oversee the implementation of the new definition, was expected to generate $\$ 41 \mathrm{~m}$ in tax revenue over four years; one legal firm speculated that the only means of achieving this would be for Treasury to 'narrow the scope of charitable activity in its definition of Charity and have the Commission take a hard line'; see Corney and Lind 2011.

${ }^{10}$ Perplexingly, para 41 claims: 'This approach is broadly consistent with Recommendation 7.1 of the PC [Productivity Commission] Report that the Australian Government should adopt a statutory definition of charitable purposes in accordance with the recommendations of the Charities Definition Inquiry' (Treasury 2011, para 41).
} 
of legal intervention. Clearly one side of the equation could not proceed without the other: the lawyers had to develop strong legal arguments for the case to succeed, but likewise, nothing would have happened without the stubborn insistence of Aid/Watch that it had a case to answer.

In fact, one might argue that the redefinition of charitable status in Australia would not have happened unless Aid/Watch had so successfully antagonized the government of the day. If Aid/Watch had not signed up for the release of political prisoners in Burma, not joined the campaign against the Australia-US Free Trade Agreement and not delivered an ironic birthday cake to the World Bank, the ATO would never have revoked its charitable status. The political disqualification, that now we understand to be unconstitutional, would still be in place. The simple lesson is that activism can produce results, both intended and unintended.

\section{References}

AAT 2008, Decision and Reasons for Decision [2008] AATA 652, para 6, AAT, Sydney.

ABC News 2007a, ‘Aid/Watch appeals charity status decision', Radio National: AM Program, 30 May.

ABC News 2007b, 'Downer dismisses Iraq aid claims', ABC News, 3 August,

ABC Radio National 2008, 'Charity in the 21st Century', The Law Report, Interview with Aid/Watch solicitor Anne Gooley, 5 August.

ABC Radio National 2009, 'When is a charity no longer a charity', In the National Interest, 25 September.

ACFID 2007, 'Aid/Watch - ATO Ruling on Charitable Status', ACFID Media Release, 30 May 2007.

ACFOA 2003, Submission to the Board of Taxation on the Draft Charities Bill, September, Australian Council for Overseas Aid, Canberra.

Aid/Watch 2009, Application's Submission, Special Leave to Appeal to the High Court, Aid/Watch, Sydney.

Aid/Watch 2010, Appellant's Submissions to the High Court, Canberra No. S82 of 2010.

ATO 2005, Income Tax and Fringe Benefits Tax: Charities, ATO Tax Ruling: 2005/21D, ATO Canberra.

ATO 2008, Respondent's Outline of Submissions, Administrative Appeals Tribunal, NT2007/1792, ATO, Canberra.

ATO 2009, Appellant's Submissions to the Federal Court, Sydney, S82 of 2010, ATO, Canberra.

ATO 2010, Respondent's Submissions to the High Court, Sydney, ATO, Canberra.

ATO 2011a, Income tax and fringe benefits tax: charities, Draft Taxation Ruling 2011/D2, ATO, Canberra.

ATO 2011b, Income tax and fringe benefits tax: charities, Taxation Ruling 2011/4, ATO, Canberra.

Australian Human Rights Commission 2009, National Human Rights Consultation, Australian Human Rights Commission Submission, June 2009, AHRC, Canberra.

Bond, P. 2008, 'Reformist reforms, non-reformist reforms and global justice: activist, NGO and intellectual challenges in the World Social Forum', Societies without Borders, vol.3, pp. 419. 
Callick, R. 2009, 'Tax battle may affect advocacy bodies’, The Australian, 23 November 2009.

Callick, R. 2010, 'Charity to challenge tax ruling', The Australian, 13 March 2009.

Commonwealth of Australia 2001, Report of the Inquiry into the Definition of Charities and Related Organisations, the 'Sheppard Inquiry', June, CDI, Canberra.

Commonwealth of Australia 2003, Charities Bill 2003: A Bill for an Act to define charities and charitable purpose and for related purposes, House of Representatives Exposure Draft, Canberra.

Commonwealth of Australia 2004, Tax Laws Amendment (2004 Measures No. 1), No. 95, Parliament of Australia, Canberra.

Corney and Lind Legal Resource Centre 2011, 'Not for Profit proposed reforms - 2011 Federal Budget', Briefing, 11 May.

Davies, B. 2007, 'Vinnies won’t be quiet on advocacy', The Catholic Weekly, 10 June 2007.

Federal Court 2009, Commissioner of Taxation v Aid/Watch Incorporated [2009] FCAFC 128, Sydney.

Federal Taxation Board 2004, Consultation on the Definition of a Charity: A Report to the Treasurer, FTB, Canberra.

Goodman, J. 2009, Aid/Watch Submission, DR238, Inquiry into the Contribution of the Not-forProfit Sector, Productivity Commission, Canberra.

Gorz, A. 1967, Strategy for Labour, Beacon Press, Boston.

High Court of Australia 2010a, Aid/Watch Incorporated v Commissioner of Taxation [2010] HCATrans 58, 12 March 2010.

High Court of Australia 2010b, Aid/Watch Incorporated v Commissioner of Taxation, HCATrans 154 (15 June 2010).

High Court of Australia 2010c, Aid/Watch Incorporated v Commissioner of Taxation, HCATrans 155 (16 June 2010).

High Court of Australia 2010d, Aid/Watch Incorporated v Commissioner of Taxation, ATC 20222, HCA 42 (1 December 2010).

Horin, A. 2009, 'Test case ruling may define charity status', Sydney Morning Herald and The Age, 11 February 2009.

Hunt, A. 1990, 'Rights and social movements: counter-hegemonic strategies', Journal of Law and Society, vol. 17, no. 3, pp. 309-328.

Irvine-So, C. 2007, 'Who's watching you? Charities, political lobbying and the Aid/Watch case', Not for Profit Briefing, Moores Legal, August 2007, pp 4-5.

Jacobs, M. 2009, 'Ruling threatens charities', Australian Financial Review, 25 September 2009.

Jopson, D. 2007, Phantom aid never leaves our shores, Sydney Morning Herald, 28 May 2007.

Lobel, O. 2007, 'The paradox of extralegal activism: critical legal consiousness and transformative politics', Harvard Law Review, vol.120, pp. 937-988.

Lyons, M. 2003, 'The Commonwealth Government and charities: conspiracy or confusion?' Briefing Paper, Centre for Australian Community Organisations and Management, University of Technology, Sydney.

Maddison, S. and Hamilton, C. 2006 'Non-Government Organisations', in Hamilton, C. and Maddison, S. (eds) Silencing dissent, Allen and Unwin, Sydney.

Marshall, T. 1950/1973, Class, citizenship and social development, Greenwood, Westport CT.

Mowbray, M. 2003, 'War on non profits: 'NGOs: what do we do about them?', Just Policy, no. 30, July, pp.3-12.

NSW Government 1984, Associations Incorporation Act, No 143, NSW, Sydney.

Oxfam Australia 2003, 'Government NGO review flawed from the outset', Media Release 7 August 2003.

Paris, M. 2006, 'The politics of rights, then and now', Law and Social Inquiry, vol.31, no.4, pp. 999-1034. 
Pearson, G. and Salter, M. 1999, 'Getting public law back into a critical condition: the rule of law as a source for immanent critique', Social \& Legal Studies, vol. 8, no.4, pp. 483-508.

Pelly, M. 2010, 'High Court puts implied right back in business', The Australian, 3 December 2010.

Philanthropy Australia 2003 'Submission to the Board of Taxation on the Draft Charities Bill', October 2003.

Phillips, R. 2006, 'The role of nonprofit advocacy organizations in Australian democracy and policy governance', Voluntas, vol. 17, no.1.

Scheingold, S. 1974/2004, The Politics of Rights: Lawyers, Public Policy and Political Change, Second Edition, University of Michigan Press, New York.

Seage, C. 2007, 'Has the Tax Office become the Government's knee-capper?', www.Crikey.com , 30 May 2007.

Senate Standing Committee on Economics 2007, Estimates Hearing, Hansard, 29 May 2007.

Senate Standing Committee on Economics 2008, Disclosure regimes for charities and not-forprofits, Hansard, 29 October 2008.

Senate Standing Committee on Economics 2009, 'Aid/Watch Charitable Status - ATO’, Additional Estimates, Hansard, 25 February 2009.

Staples, J. 2007, NGOs out in the Cold: Howard government policy towards NGOs, Democratic Audit of Australia Discussion Paper No. 19/06, as updated February 2007, University of New South Wales Law Research, Sydney.

The Australia Institute 2009, 'An Uncharitable Act: The Aid/Watch Case', Between the Lines, 26 October.

Third Sector Magazine 2009, 'Maintaining the Balance: Charitable purposes versus political agendas', Editorial, 2 October 2009.

Wade, M. 2007, 'Canberra's gagging us, say charities’, Sydney Morning Herald, 30 May 2007.

Wiggins, K. 2011, 'Points of law: the precedent of Australia', Third Sector (UK), 1 February.

Woods, E. 1995, Democracy against Capitalism: Renewing Historical Materialism, Cambridge University Press, Cambridge.

Zevnik, A. 2011, 'Becoming-Animal, Becoming-Detainee: Encountering Human Rights Discourse in Guantanamo’, Law Critique, vol.22, pp. 155-169. 